\title{
First report of charcoal rot caused by Macrophomina phaseolina on kiwifruit in Turkey
}

\author{
Muharrem Türkkan ${ }^{1}$ (1) $\cdot$ Halil ibrahim Benli ${ }^{1}$. Özkan Yılmaz ${ }^{1} \cdot$ Göksel Özer ${ }^{2} \cdot$ Mehmet Yaman $^{3} \cdot$ Nusret Şahin ${ }^{4}$. \\ Ismail Erper ${ }^{5,6}$
}

Received: 24 June 2019 / Accepted: 9 October 2019/Published online: 17 October 2019

(C) Società Italiana di Patologia Vegetale (S.I.Pa.V.) 2019

Keywords Kiwifruit $\cdot$ Macrophomina phaseolina $\cdot$ rDNA-ITS region

During June and August in 2018, kiwifruit (cv. Hayward) plants exhibiting symptoms of charcoal rot including chlorosis, necrosis, leaf shedding, root rot, and trunk dry rot were observed with an incidence of up 5\% in three commercial orchards located in Altınordu, Fatsa and Perşembe districts of Ordu province. After surface sterilization with $1 \%$ $\mathrm{NaClO}$, small pieces excised from root tissues of diseased plants were rinsed twice in sterile distilled water, dried on sterile filter papers and aseptically transferred to plates containing potato dextrose agar. Ten isolates from the plates were identified as Macrophomina phaseolina (Tassi) Goid. based on the growth characteristics, agar pigmentation, and the presence of microsclerotia 78.8 to $90.75 \mu \mathrm{m}$ in diameter $(n=30)$ (Dhingra and Sinclair 1973). To confirm the identification, the internal transcribed spacer (ITS) of rDNA of a representative isolate (KWF09) was amplified and sequenced. The resulting 537-bp sequence (GenBank accession No. MK287619) shared $99 \%$ similarity to those of $M$. phaseolina isolates CBS-231.33, CBS-457.70 and CBS-126630 (KF951631,

Muharrem Türkkan

muharremturkkan@odu.edu.tr; muharremturkkan@gmail.com

1 Plant Protection Department, Agriculture Faculty, Ordu University, 52200 Ordu, Turkey

2 Plant Protection Department, Agriculture and Natural Sciences Faculty, Abant Izzet Baysal University, 14030 Bolu, Turkey

3 Akçay Agricultural Credit Cooperative, The Agricultural Credit Cooperatives of Turkey, 07770 Antalya, Elmal1, Turkey

4 Ordu Directorate of Provincial Agriculture and Forestry, Republic of Turkey Ministry of Agriculture and Forestry, 52200 Ordu, Turkey

5 Plant Protection Department, Agriculture Faculty, Ondokuz Mayis University, 55139 Samsun, Atakum, Turkey

6 Plant Protection Department, Agriculture Faculty, Kyrgyz-Turkish Manas University, 720044 Bishkek, Kyrgyzstan
KF951636 and MH864176, respectively) in the GenBank database. The pathogenicity assay with isolate KWF09 was performed on 4-month-old kiwifruit seedlings according to Singleton et al. (1993). The seedlings were transferred to the growth chamber and kept at $28{ }^{\circ} \mathrm{C}$. Six weeks after inoculation, brown to black lesions were observed on the roots of inoculated plants, from which M. phaseolina was consistently re-isolated. Although detailed studies are needed to determine the distribution of charcoal rot in Ordu, to our knowledge, this is the first report of charcoal rot caused by M. phaseolina on kiwifruit from Turkey.

\section{Compliance with ethical standards}

Conflict of interest The authors declare no conflict of interests.

Research involving human participants and/or animals The authors declare that no human participants and animals were involved in this study.

Informed consent This manuscript is new and not being considered elsewhere. All authors have approved the submission of this manuscript.

\section{References}

Dhingra OD, Sinclair JB (1973) Location of Macrophomina phaseolina on soybean plants related to culture characteristics and virulence. Phytopathology 63:934-936

Singleton LL, Mihail JD, Rush CM (1993) Methods for research on soilborne phytopathogenic fungi. APS Press, St. Paul

Publisher's note Springer Nature remains neutral with regard to jurisdictional claims in published maps and institutional affiliations. 